\title{
Peculiarities of Legal Process of Individual Labor Disputes Resolution: a Comparative Analysis of Legislation in Some European Countries
}

\author{
By Guzal Galiakbarova ${ }^{1}$
}

\begin{abstract}
This article discusses the peculiarities of legal process of individual labor disputes resolution in some European countries and the Republic of Kazakhstan. The labour legislation in Kazakhstan is on the way of formation and requires an improvement in matters of legal regulation of individual labour disputes. This, according to the author, is possible by studying foreign experience. It should be noted that in Kazakhstan there are no specialized labour courts and thus, labour disputes are considered in civil proceedings. Accordingly, the author compares the judicial system of the Republic of Kazakhstan with the judicial system of some European countries where labour disputes are considered by general jurisdiction courts (Switzerland, France, Italy, Sweden).
\end{abstract}

Key words: Individual labor disputes, general jurisdiction courts, the European Union, the Republic of Kazakhstan.

\section{Introduction.}

At the present stage of development, the labor legislation of the Republic of Kazakhstan (RK) requires an improvement of the standards in a pre-trial review legal regulation and individual labor disputesresolution, which, in our opinion, is possible only by studying the experience of countries successful in this direction.

A Belgian scientist Professor R. Blancpain believes that "... analysis of foreign legal regulation systems of labor is a huge advantage that allows to consider its own national experience in the aspect of international experience; when learning foreign legal systems often you have to experience culture shock when you find out that a particular problem is solved completely in a different way. And this makes to analyze and assess the problem of its national labor law now at a different angle one more time, in a new aspect of a rich understanding of the nature of the problem" (Comparative Labor Law, 1993).

One of the most important tasks of comparative legal research is to compare the development of the national labor law with the global trends and on this basis to identify "the extent to which national labor law system is synchronized with these trends, if it is ahead of world development, or behind him, or moves in another opposite direction" (Schgregle, 1981).

According to a prominent Russian scientist S. Kashkin, the European Union (EU) today has the most advanced social security system in today's world, the foundations of which were laid in the first half of the XX century. However, as in any other field of activity, there is always the need for its improvement, perfection; in relation to social policy improving the living standards and social protection of citizens (Kashkin, 2012). Thus,

${ }^{1} \mathrm{PhD}$ student in Law, Department of Civil Law Disciplines, L.N. Gumilyov Eurasian National University, Kazakhstan.Astana. 
having formed EU, Member States have consolidated in the Treaty on EU (Article 2) a general agreement on the need "to promote throughout the Community ... a high level achievement in employment and social protection, equality between men and women ... raising the standard of living and quality of life" (Treaty on European Union, 1992).

That is why the study of the labor rights of foreign countries in today's globalized economics and law conditions, the growth of international economics and humanitarian contacts, is becoming a necessary part of the development of any country.

The ongoing legal reforms in European countries as well as in the Republic of Kazakhstan (the RK) in the field of labor relations reflects the idea of achieving the main objective of the labor legislation - the agreement of economic objectives and the protection of the individual, including their rights and freedoms in the field of labor.

The management principles of the performance improvement developed by the International Labor Organization declared that the "labor relations depend on the interaction between employees and employers. The nature of their interaction depends on the environment in which they operate, as well as the type of dispute that they are seeking to solve. A lot of controversy, but not all, can be resolved by the parties on the basis of consensus, dialogue and negotiation" (2013).

At the same time legislation in many countries provides for a judicial resolution of labor disputes.

There are numerous examples of the creation and operation of labor courts in the world (e.g., Austria, Germany, Brazil, Hungary, Spain, Turkey, Finland and etc.).

The activity of specialized labor justice has proven to be the necessity and usefulness as one of the institutions of social and legal infrastructure to facilitate an efficient settlement of labor disputes in the best interests of the disputing parties and society and thus ensure social peace.

The important role of the institutions of a specialized labor justice in the development of labor law, its credibility enhancement and a consolidation to achieve internal consistency, the elimination of gaps in law enforcement practice, and its improvement is generally recognized. In many countries, labor court decisions are a source of labor law (Orobets, 2003).

In spite of this, we felt it appropriate to reveal the special aspects of labor disputes of some European countries where either no labor courts or labor disputes are considered to be in the aforementioned specialized courts and courts of general jurisdiction. This is due to the fact that Kazakhstan has currently no labor courts, whereby labor disputes are considered by the courts of general jurisdiction in civil proceedings.

The above-mentioned circumstances and a number of other observations have led to the selection of the labor legislation of some EU countries in terms of the court order of individual labor disputes regulation as an object of comparison.

\section{Objectives of the study. Methodology.}

The objectives of the study are:

- To determine the characteristics of individual labor disputes resolution processes in certain European countries and in the RK; 
- To conduct a comparative analysis of the legislation of European countries where labor disputes are considered in courts of law and the civil procedural legislation of the RK; - To identify problematic aspects relating to the theme of the research in Kazakhstan; - To identify the ways of existing problems solution by the example of foreign experience.

\section{Main body of the article.}

\subsection{Special aspects of individual labor disputes resolution processes, case study of Switzerland, France, Italy, Sweden.}

In most European countries, the jurisdiction of general jurisdiction courts applies only individual labor disputes, at least - collective (Skobelkin, 2002).

In Switzerland the vast number of labor cases is considered at the courts of general jurisdiction. Special courts for the trial of labor disputes exist only in certain cantons (Berdychevski, 2004). The peculiarity of labor disputes in Switzerland is that there are two levels: the district courts (the first instance) and the cantonal appeal courts (the second or the court of cassation). The supreme judicial body is the Federal Court. In the Federal Court the labor relations are considered only in certain cases. We can take as an example a situation where the parties have agreed to submit the dispute to it in the first instance by that court, where the amount in dispute exceeds the statutory amount. At the Federal Court there are houses to review civil and criminal cases and the cases related to insolvency and bankruptcy, etc.

The peculiarity of proceedings in Switzerland is that the burden of proof is shared between the parties. This means that the court is not bound by the claims and in making decisions may go beyond them. Only the judgments with a high amount of a claim come under the revision or withdrawal (Skobelkin, 2002). A simplified special appeal procedure is provided. It is used in cases when the court considers a complaint against the decision of the lower court "clearly justified" or, on the contrary, "clearly unjustified". The decisions on such complaints are adopted in a closed session by the court consisting of three persons (but only on the condition that it is adopted unanimously).

In France, the general jurisdictioncourts consider only the cases, the cause of which is a violation of law. If the employee disputes the position of the collective agreement included in the text of the individual labor contract, then he should apply to the employment court. The Court on a parity basis consists of representatives of employers and employees. Candidates are offered by employers' associations and trade unions (Code du travail).

In Italy, the general jurisdiction courts consider the disputes relating to labor relations of employees in the private and public sector (including public servants, except the cases where the law establishes a different procedure for dealing with complaints for certain categories of officials) and others.

At the first instance, the dispute is heard by a judge (Pretoria) alone. It uses, as already noted, the simplified procedure, relying mainly on the testimony, and the arguments of the parties. At the same time the court fees for labor affairs shall not charge, the cost of attorneys' fees is required to compensate for the losing side. 
An interested party may appeal the decision of Pretoria to the Court of Appeals, which reviews the case of three judges. The highest judicial authority is the Court of Cassation, in which labor relations are transferred to the special board.

In Italy, the employer fails to timely comply with the decision of the court for reinstatement, the employee shall pay a commensurate compensation for lost wages. However, if the employee within 30 days after the judgment is not down to work, the employer is removed from its performance obligation.

The peculiarity of labor disputes in Sweden is expressed in the fact that individual labor disputes of employees, who are not members of trade unions, are considered by the courts of general jurisdiction. If the employee is not satisfied with how the trade union defends its interests, or if the union refused to file a law suit on behalf of an employee to a labor court, he also has a right to appeal to an ordinary court. An ordinary civil court decision can be appealed to the Labor Court.

\subsection{Discussion of problematic issues in the Republic of Kazakhstan.}

In Kazakhstan the judicial protection of labor rights shall be in the general jurisdictioncourts and has some special peculiarities, as they will be discussed below.

Judicial protection is a universal form of protection of violated rights. The right to judicial protection guaranteed by the Constitution of the RK is a guarantee in respect of all other constitutional rights and freedoms, including the rights and freedoms at work (The Constitution of the RK, 1995). This right in itself is universal and is not subject to any restrictions. The presence of other forms of protection does not deprive the right to judicial protection.

The Constitution of the RK in article 37 enshrinesthe right to individual labor disputes with the use of their resolution methods specified by law including the legal process (The Constitution of the RK, 1995).

The right of the subjects to appeal a labor dispute in court is also provided in the norms of the Labor Code of the RK, Civil Procedure Code of the RK (CPC of the RK) and other laws.

The court can consider any individual labor dispute, as the pretrial procedure of consideration of individual labor disputes at the conciliation commission is not binding for either category of individual labor disputes.

Labor disputes shall be referred to the courts of general jurisdiction under the general rules for a few exceptions. The claims are brought in the court for the location of a defendant, i.e., for legal or actual location of the legal person - the employer.

The consideration of individual labor disputes in the court is different from the review of other civil disputes, as characterized by a number of procedural features (Kurennoi, 2008).

Firstly, a worker has the right to apply to the court for individual labor dispute resolution. He may initially go to court without going to the conciliation commission for permission to any individual labor dispute and also appeal against the decision of the conciliation commission in court if he initially applied to a conciliation commission and he didn't agree with its decision. The employer has also the right to appeal to the court, firstly, with a statement for the caused damage reimbursement by the employee, and 
secondly, if he does not agree with the decision of the conciliation commission at the request of the worker, and wants to appeal it in court.

Secondly, the procedural peculiarities should include deadlines for applying to court.

Labor relations are considered and resolved within two months from the date of receipt of the application to the court. Only the case for reinstatement shall be considered and resolved in the period of one month (Art. 174 of CPC of the RK). In our view, in the absence of the Labor Code of the RK article about the timing of going to court for resolution of individual labor disputes, as well as the consideration and resolution of labor disputes in court along with other civil disputes does not fully solve the problem of the protection of workers' rights.

In practice, there are situations when the parties of the employment contract, and often a worker, knowing of the absence of any reference to court, does not hurry to receive documents which confirm the violation of his rights at work, so as a result here come: the loss of evidence, the absence of witnesses, process participants, etc. At the same time the employer does not hurry up too, for example, he does not submit a copy of the order of dismissal, work book in time, does not make timely recordings, etc. The loss of evidence in the absence of terms to court ultimately makes it impossible to objectively understand the essence of the case and to make the right decision.

Unfortunately, the Chapter 15 of the Labor Code of the RK has absolutely no mention of consideration of individual labor disputes in court. The fact that the employee may choose to apply for settlement of labor disputes or the conciliation commission or the court does not solve the problem, which implies that the parties can live without prior negotiation. We believe that the conciliation commission shall be a mandatory primary body for the consideration of individual labor disputes between employer and employee, with the exception of disputes directly examined by district courts. Thus, the labor codes of some countries of the Commonwealth of Independent States recognize the pre-trial body for consideration of individual labor disputes a mandatory primary body for the consideration of labor disputes (e.g., Art. 236 of the Labor Code of Belarus).

The issue of an immediate execution of some decisions and resolutions on labor affairs also requires a serious approach, as article 237 of CPC of the RK which states the fact of the need for an immediate court decision on reinstatement; the award of employee wages, but not more than three months; for damages caused by injury or other impairment of health, as well as the loss of a breadwinner, but not more than three months, does not adequately protect the interests of workers. In this article, for example, we cannot see how the worker is recovering: for the same or other work, at the same or another job, with or without saving significant labor conditions. And if an organization where the employee has previously worked does not exist any longer (liquidated or reorganized), then what to do?

\section{Conclusions.}

Analyzing the above peculiarities we see that in some countries they deal with labor disputes using the normal rules of civil procedure (for example, in the Netherlands, as well as in Kazakhstan, in the courts there is a huge number of cases that adversely affects the timing of the decisions), in others - a simplified procedure, whereby the 
process of settlement of the case by the judge specializing in employment law is considerably accelerated (e.g. Italy).

Due to the fact that at present it is not possible to establish specialized labor courts in Kazakhstan, we think that ensuring the effective protection of labor rights of employees, the establishment of a decent standard of legal safeguards in the workplace objectively requires the study of foreign experience in the field of consideration of individual labor disputes courts of general jurisdiction, because the working rules of the Labor Code of the RK are in the process of establishing the compliance with the universally recognized principles of international labor law.

\section{Acknowledgments.}

The author expresses gratitude to the Professor of the Department of Civil Law Disciplines of L.N. Gumilyov Eurasian National University and the research supervisor Enlik Nurgalieva for the scientific guidelines and support.

\section{References.}

ГражАанский процессуальный кодекс Республики Беларусь: от 11 января 1999 года (с изменениями и Аополнениями по состоянию на 1 июля 2014 года) // Информационная система «Параграф». - 2015.

Гражданский процессуальный кодекс Республики Казахстан: от 13 июля 1999 года (с изменениями и Аополнениями по состоянию на 24 апреля 2015 года) // Информационная система «Параграф». - 2015.

TreatyonEuropeanUnion//

http:/ / europa.eu/eu-law/decisionmaking/treaties/pdf/treaty_on_european_union/treaty_on_european_union_en.pdf

Конституция Республики Казахстан: от 30 августа 1995 года // Информационная система «Параграф». - 2015.

Трудовой кодекс Республики Казахстан: от 15 мая 2007 года (с изменениями и дополнениями по состоянию на 21июля 2015 года) // Информационная система «Параграф». - 2015.

Codedutravail (Трудовой кодекс Франции) // http://www.legifrance.gouv.fr.

Бердычевский В.С. О концепции формирования специализированных трудовых судов и трудового процессуального кодекса / Проблемы защиты трудовых прав граждан: М-лы науч.-практ. конференции. М., 2004.

Comparative Labour Law and Industrial Relations in Industrialized Market Economies.Deventer, 1993.

Оробец В.М. Специализированные трудовые суды: зарубежный опыт и российское законодательство // Журнал российского права. 2003. № 9.

Право Европейского Союза: учебное пособие / С.Ю. Кашкин, А.О. Четвериков, П.А. Калиниченко [и Ар.]; отв. ред. С.Ю. Кашкин. - 3-е изА., перераб. и доп. - Москва: Проспект, 2012. - 320 с.

Скобелкин В.Н., Перелерин С.В., Чуча С.Ю., Семенюта Н.Н. Трудовое процедурно-процессуальное право: Учеб. пособие / Под реА. В.Н. Скобелкина. - Воронеж: ИзАательство Воронежского государственного университета, 2002. - 504 с.

Трудовое право России // Под реА. А.М. Куренного. - 2-е изА., испр. и Аоп. - М.: Издательский дом «Правоведение», 2008.

Labour dispute systems: guidelines for improved performance. International Training Centre of the ILO, 2013.

Schgregle J. Comparative industrial relations: pitfalls and potentials. // International Labour Review. 1981. № 1 . 